\title{
Lactobacillus plantarum st202ch and lactobacillus plantarum st216ch -what are the limitations for application?
}

\begin{abstract}
Lactobacillus plantarum ST202Ch and Lactobacillus plantarum ST216Ch, isolated from Beloura and Chourico (Portuguese fermented meat products), produced bacteriocins active against a number of Gram-positive and Gram-negative meat spoilage bacteria and Mycobacterium tuberculosis. In addition, Lb. plantarum ST202Ch and Lb. plantarum ST216Ch presented a good potential to be considered as probiotic candidates based on the genetic and physiological tests. However, before using both strains as biopreservatives and probiotic cultures, other investigations are in progress to assess their safety and virulence traits potentially hindering their applications in meat production processes.

This work first screened both $L b$. plantarum strains for the occurrence of several bacteriocin genes. $\mathrm{Lb}$. plantarum ST202Ch generated positive results for the presence of pediocin PA-1 genes and no evidences for nisin, plantaricin S, plantaricin W and plantaricin NC8. On the other hand, $L b$. plantarum ST216Ch gave no evidences for all the bacteriocins genes targeted in this study. Bacteriocins produced by $L$ b. plantarum ST202Ch and Lb. plantarum ST216Ch have been partially purified by ammonium sulphate precipitation and hydrophobic chromatography on $\mathrm{SepPakC}_{18}$ column. Semi-purified bacteriocins presented a very high activity against Listeria monocytogenes, Staphylococcus aureus and Enterococcus faecalis. However, when semi-purified bacteriocin ST202Ch and bacteriocin ST216Ch (fraction $40 \%$ iso-propanol in $25 \mathrm{mM}$ phosphate buffer, $\mathrm{pH} 6.5$ ) at $50 \mu \mathrm{g} / \mathrm{mL}$ protein concentration have been tested for cytotoxicity, only $56.1 \%$ and $65.8 \%$ survival of human hepatocytes cells (Huh7.5) were recorded. At lower protein concentration $(25 \mu \mathrm{g} / \mathrm{mL})$, the bacteriocins were not cytotoxic. Based on these results, cytotoxicity of bacteriocin ST202Ch and bacteriocin ST216Ch corresponded to $\mathrm{CC}_{50}$ of about $50-100 \mu \mathrm{g} / \mathrm{mL}$. According to these preliminary results, $L b$. plantarum ST202Ch and $L b$. plantarum ST216Ch could be used as biopreservatives cultures in meat production processes. However, further in vitro and in vivo investigations are needed towards their applications as probiotics.
\end{abstract}

Keywords: Lactobacillus plantarum, bacteriocin, cytotoxicity
Volume I Issue 2 - 2014

\author{
Bruno M Carneiro,' Ana Claudia S Braga,' \\ Mariana N Batista,' Paula Rahal,' Lorenzo \\ Favaro, ${ }^{2}$ Ana Lucia B Penna, ${ }^{3}$ Svetoslav D \\ Todorov, ${ }^{1,4}$ \\ 'Department of Biology, Sao Paulo State University, Brazil \\ ${ }^{2}$ Department of Agronomy Food Natural resources Animals and \\ Environment, University of Padova, Italy \\ ${ }^{3}$ Department of Engineering and Food Technology, Sao Paulo \\ State University, Brazil \\ ${ }^{4}$ Department of Food and Experimental Nutrition, Sao Paulo \\ State University, Brazil
}

\begin{abstract}
Correspondence: Svetoslav Dimirov Todorov, Faculty of Pharmaceutical Sciences, Department of Food and Experimental Nutrition, Laboratory of Food Microbiology, University of Sao Paulo,Av. Linnaeus Prestes 580 BI I4, 05508-000 Sao Paulo, SP, Brazil,Tel 55 I |26480054, Fax 55 I | 26480054, Emailslavi310570@abv.bg
\end{abstract}

Received: May 06, 2014 | Published: May 24, 2014

\section{Introduction}

In the last few decades consumers increased their demand for natural and chemical additive-free products urging the food industry to look for novel and alternative strategies for food biopreservation. One of the proposed routes was the use of bacteriocins produced by lactic acid bacteria (LAB), defined as ribosomally synthesized antimicrobial peptides that exhibit antagonism mainly against Grampositive bacteria.

LAB consists of a promising group of bacteriocin-producing microorganisms due to their GRAS (Generally Recognized as Safe) status, which indicates their safe and easy application as food preservatives. $^{2}$ At the present time, only nisin and pediocin PA-1 are commercially authorized worldwide depending on local law regulation.

Several LAB have been described as bacteriocin producers. Bacteriocins are generally low molecular weight proteins that gain entry into target cells by binding to cell surface receptors. Their bactericidal mechanism varies and may include pore formation, degradation of cellular DNA, disruption through specific cleavage of 16S rDNA, and inhibition of peptidoglican synthesis. ${ }^{3,4}$

Chourico and Beloura are traditional smoked meat products produced in Portugal. Chourico, also known as Chorizo, is pork sausage typical of the Iberian Peninsula and is consumed fresh, cooked or fermented. ${ }^{5}$ Two bacteriocinogenic strains of $L b$. plantarum (ST202Ch and ST216Ch) were previously isolated from Chourico and Beloura. Lb. plantarum ST202Ch and Lb. plantarum ST216Ch produce $3.5 \mathrm{kDa}$ and $10 \mathrm{kDa}$ bacteriocins, respectively, active against different species of Gram-positive and Gram-negative meat spoilage bacteria and Mycobacterium tuberculosis. ${ }^{6,7}$ In addition $L b$. plantarum ST202Ch and ST216Ch presented a good potential as probiotic candidates based on the genetic and physiological tests. ${ }^{7}$ The bacteriocin production by starter cultures may bring advantage to these strains in competitive interactions with pathogenic bacteria from the food matrix. Favaro et al. ${ }^{7}$ reported that auto-aggregation was strain-specific, and values of $16.95 \%$ and $14.58 \%$ for L. plantarum ST202Ch and $L b$. plantarum ST216Ch, respectively. Various degrees of co-aggregation between $28.85 \%$ and $44.76 \%$ for Listeria monocytogenes 211 and 409 , and between $23.60 \%$ to $34.96 \%$ for $\mathrm{E}$. faecium ATCC 19443 were observed. According to the results of the diffusion method, the studied strains demonstrated susceptibility to penicillin G, ampicillin, amoxicillin, amoxicillin/clavulonic acid, imipenem, linezolid, and tetracycline. In addition, the susceptibility of $\mathrm{Lb}$. plantarum ST202Ch and $\mathrm{Lb}$. plantarum ST216Ch to various non-antibiotic commercial drugs was previous examined. ${ }^{7}$ Production of $\beta$-galactosidase by $\mathrm{Lb}$. plantarum ST202Ch and $\mathrm{Lb}$. plantarum ST216Ch was confirmed by employing sterile filter paper discs impregnated with o-nitrophenyl- $\beta$-D-galactopyranose. A statistically significant $(\mathrm{P}<0.001)$ inhibition of Mycobacterium tuberculosis 
growth by bacteriocins produced by $L b$. plantarum ST202Ch (38.3\%) and $L b$. plantarum ST216Ch $(48.6 \%)$ was observed. As determined by the polymerase chain reaction, the tested strains showed a low virulence gene profile.?

Although many papers evaluated a wide range of bacteriocins produced by $L b$. plantarum that are active against specific pathogens, very few $L b$. plantarum strains have been studied in a complete and organized manner. ${ }^{8}$ As a result, deeper characterization of the safety of producer and its bacteriocins is essential for their successful application in food industry. ${ }^{9}$ This work focused on the safety investigation of $L b$. plantarum ST202Ch and $L$ b. plantarum ST216Ch in terms of presence of genes encoding bacteriocins and assessment of the potential cytotoxicity of expressed bacteriocins.

\section{Materials and methods}

\section{Strains and media}

Lb. plantarum ST202Ch and $\mathrm{Lb}$. plantarum ST216Ch bacteriocinogenic strains were isolated from Chourico and Beloura $^{6}$ and L. monocytogenes, St. aureus and E. faecalis as test microorganisms were cultured in MRS broth and BHI broth (Difco, Detroit, MI, USA), respectively at $30^{\circ} \mathrm{C}$ and stored at $-80^{\circ} \mathrm{C}$, in presence of $20 \%$ glycerol.

Differentiation of the strains was by random amplification of polymorphic DNA (RAPD) PCR. Genomic DNA was extracted from Lb. plantarum ST202Ch and Lb. plantarum ST216Ch using a DNA extraction kit (Zymo Research, USA). Primers OPL-05, OPL-08 and OPL-20 (Kit L of the RAPD ${ }^{\circledR}$ lomer kits, Operon Biotechnologies, Cologne, Germany) were used. Amplification reactions were performed according to Todorov et al. ${ }^{10}$ The $50 \mu \mathrm{L}$ reaction volume contained $10 \mu \mathrm{L}$ primer, $5.0 \mu \mathrm{L} 10 \mathrm{x}$ rTaq Buffer (Takara Bio Inc, Shiga, Japan), $20 \mu \mathrm{L} 5 \mathrm{mM} \mathrm{MgCl} 2$ (Roche), $8 \mu \mathrm{L} 2.5 \mathrm{mM}$ dNTP (Takara Bio Inc, Shiga, Japan) and 1.0 $\mu \mathrm{L}$ rTaq DNA polymerase (Takara Bio Inc, Shiga, Japan). Amplification was as follows: 45 cycles of 1 min per cycle at $94^{\circ} \mathrm{C}$, and $1 \mathrm{~min}$ at $36^{\circ} \mathrm{C}$, followed by an increase to $72^{\circ} \mathrm{C}$ over $2 \mathrm{~min}$. Extension of the amplified product was at $72{ }^{\circ} \mathrm{C}$ for $5 \mathrm{~min}$. The amplified products were separated by electrophoresis in $1.4 \%$ $(\mathrm{w} / \mathrm{v})$ agarose gels in $0.5 \mathrm{x}$ TAE buffer at $100 \mathrm{~V}$ for $2 \mathrm{~h}$. Gels were stained in TAE buffer containing $0.5 \mu \mathrm{g} / \mathrm{ml}$ ethidium bromide (Sigma Diagnostics, St. Louis, Mo., USA). Banding patterns were analysed using Gel Compare, Version 4.1 (Applied Maths, Kortrijk, Belgium).

Screening for bacteriocin production genes in $\mathbf{L b}$. plantarum ST202Ch and Lb. plantarum ST2 I 6Ch

Lb. plantarum ST202Ch and $\mathrm{Lb}$. plantarum ST216Ch were investigated for the presence of known bacteriocin genes (plantaricin $\mathrm{S}$, plantaricin NC8, plantaricin $\mathrm{W}$, pediocin PA-1 and nisin) using PCR and the primers according to Albano et al., ${ }^{11}$ Marugg et al., ${ }^{12}$ Kruger et al., ${ }^{13}$ Martinez et al. ${ }^{14}$ Total DNA was extracted using ZR Fungal/ Bacterial DNA Kit (Zymo Research, Irvine, CA, USA) and submitted to the amplification in a reaction mixture according to Albano et al., ${ }^{11}$ Marugg et al., ${ }^{12}$ Kruger et al., ${ }^{13}$ Martinez et al. ${ }^{14}$ Amplification was achieved in 35 cycles using a DNA thermocycler MasterCycler ${ }^{\circledR}$ PCR (Eppendorf Scientific) according to Albano et al., ${ }^{11}$ Marugg et al., ${ }^{12}$ Kruger et al., ${ }^{13}$ Martinez et al. ${ }^{14}$ PCR-amplified DNA fragments were separated by $0.8 \%$ to $2 \%(\mathrm{w} / \mathrm{v})$ agarose gel electrophoresis, stained with ethidium bromide $(0.1 \mathrm{mg} / \mathrm{mL})$ and visualized using the UVP BioImaging System (DIGIDOC-IT System). For each primer, the corresponding bands were purified with QIAquick ${ }^{\circledR}$ PCR Purification kit (Qiagen) according to the manufacturer's instructions and submitted to sequencing. The sequences were compared to those deposited in GenBank, using the BLAST algorithm. ${ }^{15}$

\section{Bacteriocin test and partial purification of bacteriocin/s expressed by Lb. plantarum ST202Ch and Lb. plantarum ST2 I $6 \mathrm{Ch}$}

Cell-free supernatant obtained from a $24 \mathrm{~h}$ culture of $\mathrm{Lb}$. plantarum ST202Ch and $L b$. plantarum ST216Ch were prepared and tested for production of bacteriocin/s as described by Todorov et al. ${ }^{6}$ Bacteriocins were precipitated by addition of ammonium sulfate to the cell-free supernatant to obtain $60 \%$ saturation and stirred for $4 \mathrm{~h}$ at $4^{\circ} \mathrm{C}$. After centrifugation for $1 \mathrm{~h}$ at $12,000 \mathrm{~g}$ at $4^{\circ} \mathrm{C}$, the resulting pellet was re-suspended in $100 \mathrm{~mL}$ of $25 \mathrm{mM}$ ammonium acetate buffer $(\mathrm{pH}$ 6.5), and loaded on SepPak $\mathrm{C}_{18}$ cartridge (Waters, Millipore, MA, USA), and bacteriocins eluted with $40 \%$ and $60 \%$ iso-propanol in $25 \mathrm{mM}$ ammonium acetate buffer ( $\mathrm{pH}$ 6.5). The active fractions were dried under vacuum (Speed-Vac, Savant, France) and the bacteriocin fraction was re-suspended in sterile distilled water and filtered using $0.22 \mu \mathrm{m}$ pore size filter units (Waters). Bacteriocin production have been performed against Listeria monocytogenes 211 and 409 and E. faecium ATCC 19443 according to Todorov et al. ${ }^{6}$

\section{Cytotoxicity of bacteriocins produced by Lb. plantarum ST202Ch and Lb. plantarum ST2 I 6Ch}

Cytotoxicity was assessed using human hepatocellular carcinoma cells (Huh7.5) as previously described by James et al. ${ }^{3}$ The results were calculated by regression analysis and expressed as CC50, which corresponds to the concentration of bacteriocin $(\mu \mathrm{g} / \mathrm{mL})$ needed to lower the cell viability to $50 \%$.

\section{Results and discussion}

Differentiation of Lb. plantarum ST202Ch and Lb. plantarum ST2I6Ch and screening for presence of bacteriocin genes

RAPD-PCR analysis with primers OPL-05, OPL-08 and OPL20 showed a significant difference between isolates ST202Ch and ST216Ch (data not shown), suggesting that the two isolates are genetically different. ${ }^{16}$ These results have been confirmed with the further determination for the presence of bacteriocins (in this study), virulence factors, biogenic amines and antibiotic resistance genes. ${ }^{17}$

On the basis of the PCR reactions performed targeting plantaricin $\mathrm{S}$, plantaricin NC8, plantaricin $\mathrm{W}$, pediocin PA-1 and nisin, $L b$. plantarum ST202Ch generated positive results for pediocin PA-1 gene, whereas no evidences were recorded for $L b$. plantarum ST216Ch. L. plantarum ST202Ch harbors a 1044bp fragment corresponding to that recorded for pediocin PA-1. The sequences of the PCR product using DNA from $L b$. plantarum ST202Ch was identical to that reported for pediocin PA-1. ${ }^{12}$ Pediocin PA-1 biosynthesis involves a DNA fragment of approximately $3.5 \mathrm{~kb}$, comprising the four genes pedA, pedB, pedC, and pedD. ${ }^{12}$ This result shows that bacST202Ch shares a high homology with pediocin PA-1. In addition Lb. plantarum ST202Ch harbors a 203bp fragment corresponding to that recorded for nisin F. The sequence of the generated PCR product using DNA from $\mathrm{Lb}$. plantarum ST202Ch was highly $(98 \%)$ identical to that reported for nisin $\mathrm{F}^{13,18}$ 
However, purification, mass spectrometry and amino-acid sequence of the expressed bacteriocins by $L$ b. plantarum ST202Ch will be needful in order to

i) Confirm if strain ST202Ch really expresses pediocin PA-1 and

ii) Evaluate the extent of identity of bacteriocin secreted by ST216Ch with the already available sequences of pediocin PA-1.

Considering the spectrum of activity and molecular size of the secreted bacteriocins ${ }^{6} \mathrm{Lb}$. plantarum ST202Ch most probably produces antimicrobial peptide(s) different from pediocin PA-1. To further investigate this aspect, we have purified and sequenced the putative PA-1 amplicon obtained with $\mathrm{Lb}$. plantarum ST202Ch. The resulting sequence displayed high homology ( $>98 \%)$ when compared to sequences previously deposited in the GenBank for pediocin PA1. However, additional experiments on bacteriocin purification and amino-acid sequence of the expressed bacteriocin(s) are required in order to confirm the expression of the detected pediocin gene in $L b$. plantarum ST202Ch.

Very frequently authors report new bacteriocin identification based only on the determination of the presence of gene(s) for bacteriocin $/ \mathrm{s}$ production. ${ }^{18,19}$ Albano et al. ${ }^{11}$ have pointed the presence of pediocin PA-1 genes in two different strains of P. acidilactici isolated from "Alheira". The evidences for the expression of this bacteriocin are not reported in cited works ${ }^{11,18,19}$ and it can only be surmised whether these bacteriocins were expressed or not. The purification of the bacteriocin followed by mass spectrometry and amino acid sequencing (even only partial sequence or amino acid composition) is a proof that the genes are being expressed. ${ }^{20}$ It was shown that some bacteriocin producer strains may carry several genes for bacteriocin production and depend of the growth conditions to express one or other gene. ${ }^{21}$

\section{Bacteriocin purification and cytotoxicity of expressed bacteriocins (ST202Ch and ST2 I 6Ch)}

Bacteriocins produced by $L b$. plantarum ST202Ch and $L b$. plantarum ST216Ch have been partially purified by ammonium sulphate precipitation and hydrophobic chromatography on $\mathrm{SepPakC}_{18}$ column. Semi-purified bacteriocins disclosed very high activity against L. monocytogenes, St. aureus and E. faecalis. However, when semi-purified bacteriocins ST202Ch and ST216Ch (fraction $40 \%$ iso-propanol in $25 \mathrm{mM}$ phosphate buffer, $\mathrm{pH} 6.50$ ) at $50 \mu \mathrm{g} / \mathrm{mL}$ protein concentration have been tested for cytotoxicity, only $56.1 \%$ and $65.8 \%$ survival of human hepatocellular carcinoma cells (Huh7.5) were detected. Nevertheless, no toxicity has been observed on Huh 7.5 cells with $25 \mu \mathrm{g} / \mathrm{mL}$ protein concentration. Based on these results, cytotoxicity of bacteriocin ST202Ch and bacteriocin ST216Ch corresponded to CC50 of about $50-100 \mu \mathrm{g} / \mathrm{mL}$. Application of both bacteriocins in semi-purified or purified preparations in food will need to be considered with attention to the level of their cytotoxicity. To this regard, it is important to compare the extent of cytotoxicity detected in this study with relative data reported for other bacteriocins. Unfortunately, only a few bacteriocins have been previously characterized regarding their cytotoxicity., ${ }^{3,22-24}$ Vaucher et al. ${ }^{24}$ reported cytotoxicity for antimicrobial peptide P34 and nisin. Vero cells were treated with different concentrations $(0.02-2.5 \mu \mathrm{g} / \mathrm{mL})$ of antimicrobial peptide P34 and nisin. The EC50 values of the peptide P34 were 0.60 and $1.25 \mu \mathrm{g} / \mathrm{mL}$ respectively, while values of nisin assessed as 0.50 and $1.04 \mu \mathrm{g} / \mathrm{mL}$. Determination of the cytotoxicity is an important parameter in the characterization of bacteriocins in order to recommend their application for food biopreservation or as an alternative to antibiotics in medical practice.

\section{Conclusion}

Besides all beneficial properties studied for various $\mathrm{LAB}$, a special attention needs to be paid on the possible presence of virulence factors, production of biogenic amines and antibiotic resistance. These virulence determinants have been well detected and studied in Enterococci and Streptococci. Nonetheless, in last fewyears, reports on the presence of virulence factors in otherwise GRAS Lactobacilli demonstrated potential upcoming problems for their applications in food industry. Horizontal gene transfer of virulence factors between pathogenic and $\mathrm{LAB}$, including probiotics is a highly possible scenario in case of uncontrolled application of probiotics.

The preliminary results of this study indicate that $L b$. plantarum ST202Ch and Lb. plantarum ST216Ch, isolated from Chourico and Beloura for their promising antimicrobial activities, could be used as biopreservatives cultures in meat production processes. However, the level of cytotoxicity determined for their bacteriocins has to be further evaluated before the application of both strains as probiotics.

\section{Acknowledgements}

None.

\section{Conflict of interest}

Author declares that there is no conflict of interest.

\section{References}

1. Barbosa J, Gibbs PA, Teixeira P. Virulence factors among enterococci isolated from traditional fermented meat products produced in the North of Portugal. Food Control. 2010;21(5):651-656.

2. Nishie M, Nagao J, Sonomoto K. Antibacterial peptides "bacteriocins": an overview of their diverse characteristics and applications. Biocontrol Sci. 2012;17(1):1-16.

3. James R, Lazdunski C, Pattus F. Bacteriocins, microcins and lantibiotics. New York: Springer-Verlag; 1991.

4. De Vuyst L, Vandamme EJ. Bacteriocins of lactic acid bacteria. London, England: Blackie Academic \& Professional; 1994.

5. Todorov SD, Favaro L, Gibbs P, et al. Enterococcus faecium isolated from Lombo, Portuguese traditional sausage: characterization of antibacterial compounds and study of the factors affecting bacteriocin production. Beneficial Microbes. 2012;3(4):319-330.

6. Todorov SD, Ho P, Vaz-Velho M, et al. Characterization of bacteriocins produced by two strains of Lactobacillus plantarum isolated from Beloura and Chourico, traditional pork products from Portugal. Meat Sci. 2010;84(3):334-343.

7. Favaro L, Basaglia M, Casella S, et al. Bacteriocinogenic potential and safety evaluation of non-starter Enterococcus faecium strains isolated from home made white brine cheese. Food Microbiol. 2014;38:228-239.

8. Todorov SD. Bacteriocins from Lactobacillus plantarum - production, genetic organization and mode of action. Braz $J$ Microbiol. 2009;40(2):209-221.

9. Gomes BC, Esteves CT, Palazzo IC, et al. Prevalence and characterization of Enterococcusspp. isolated from Brazilian foods. Food Microbiol. 2008;25(5):668-675. 
10. Todorov SD, Wachsman M, Tome E, et al. Characterisation of an antiviral pediocin-like bacteriocin produced by Enterococcus faecium. Food Microbiol. 2010;27(7):869-879.

11. Albano H, Todorov SD, van Reenen CA, et al. Characterization of two bacteriocins produced by Pediococcus acidilactici isolated from "Alheira", a fermented sausage traditionally produced in Portugal. Int J Food Microbiol. 2007;116(2):239-247.

12. Marugg JD, Gonzalez CF, Kunka BS, et al. Cloning, expression, and nucleotide sequence of genes involved in the production of pediocin PA1, and bacteriocin from Pediococcus acidilacticiPAC1.0. Appl Environ Microbiol. 1992;58(8):2360-2367.

13. Kruger MF, Barbosa MS, Miranda A, et al. Isolation of bacteriocinogenic strain of Lactococcus lactis subsp. lactis from rocket salad (Eruca sativa Mill.) and evidences of production of a variant of nisin with modification in the leader-peptide. Food Control. 2013;33(2):467-476.

14. Martinez RC, Wachsman M, Torres NI, et al. Biochemical, antimicrobial and molecular characterization of a noncytotoxic bacteriocin produced by Lactobacillus plantarum ST71KS. Food Microbiol. 2013;34(2):376-381.

15. http://www.ncbi.nlm.nih.gov/BLAST

16. Eaton TJ, Gasson MJ. Molecular screening of Enterococcus virulence determinants and potential for genetic exchange between food and medical isolates. Appl Environ Microbiol. 2001;67(4):1628-1635.

17. Todorov SD, Franco BD, Wiid IJ. In vitro study of beneficial properties and safety of lactic acid bacteria isolated from Portuguese fermented meat products. Benef Microbes. 2014:1-16.
18. De Kwaadsteniet M, Douschate KT, Dicks LMT. Characterization of the structural gene encoding Nisin F, a new lantibiotic produced by a Lactococcus lactissubsp. lactis isolate from freshwater catfish (Clarias gariepinus). Appl Environ Microbiol. 2008;74(2):547-549.

19. De Kwaadsteniet M, Fraser T, Van Reenen CA, et al. Bacteriocin T8, a novel class IIa sec-dependent bacteriocin produced by Enterococcus faecium $\mathrm{T} 8$, isolated from vaginal secretions of children infected with human immunodeficiency virus. Appl Environ Microbiol. 2006;72(7):4761-4766.

20. Zendo T, Fukao M, Ueda K, et al. Identification of the lantibiotic nisin Q, a new natural nisin variant produced by Lactococcus lactis 61-14 isolated from a river in Japan. Biosci Biotechnol Biochem. 2003;67(7):1616-1619.

21. Poeta P, Costa D, Rojo-Bezares B, et al. Detection of antimicrobial activities and bacteriocin structural genes in faecal enterococci of wild animals. Microbiol Res. 2007;162(3):257-263.

22. Todorov SD, Wachsman MB, Knoetze H, et al. An antibacterial and antiviral peptide produced by Enterococcus mundtii ST4V isolated from soy beans. Int J Antimicrob Agents. 2005;25(6):508-513.

23. Todorov SD, Botes M, Guigas C, et al. Boza, a natural source of probiotic lactic acid bacteria. J Appl Microbiol. 2008;104(2):465-477.

24. Vaucher RA, da Motta Ade S, Brandelli A. Evaluation of the in vitro cytotoxicity of the antimicrobial peptide P34. Cell Biol Int. 2010;34(3):317-323. 